Gut, 1976, 17, 27-32

\title{
Oral administration of a chymotrypsin-labile peptide - a new test of exocrine pancreatic function in man (PFT)
}

\author{
K. GYR, ${ }^{1}$ G. A. STALDER, I. SCHIFFMANN, C. FEHR, D. VONDERSCHMITT, \\ AND H. FAHRLAENDER
}

From the Department of Gastroenterology, Medizinische Universitaetsklinik and Poliklinik, Basel, Switzerland

SUMMARY One gram N-benzoyl-L-tyrosyl PABA was orally administered to 24 controls, 15 patients with chronic exocrine pancreatic disease, 13 patients after an attack of acute pancreatitis, two patients with gluten-sensitive enteropathy, and 10 patients with biliary tract disease, peptic ulcer, or other pathology of the gastrointestinal tract. In the presence of chymotrypsin, PABA is split from the peptide and excreted in the urine. The amount of PABA excreted serves as a parameter of exocrine pancreatic function. In 51 patients, exocrine pancreatic secretion was also assessed by the Lundh test. In the control group a mean of $59 \cdot 6 \pm 12.2 \%$ (mean \pm 2 SD) of the peptide-PABA was excreted over a period of six hours. PABA excretion in exocrine pancreatic deficiency was significantly less $(P<0.001)$ than in controls. With one exception no overlap of data was noted. In the group with exocrine pancreatic deficiency, a significant relationship was shown between the PFT and the Lundh test. Reproducibility in duplicate tests was excellent. The present data justify further investigation of this procedure as a possible new oral test of exocrine pancreatic function.

In 1972 Imondi et al. reported reliable results in animals with a pancreatic function test involving the oral administration of a chymotrypsin-labile peptide which contains para-aminobenzoic acid (PABA) as a tracer group (Fig. 1). In the small bowel, in the presence of chymotrypsin, the peptide is split resulting in the liberation of PABA, which is rapidly absorbed from the gut, undergoes conjugation in the liver, and is excreted in the urine. The amount of PABA recovered in the urine during a certain time is used as an index of exocrine pancreatic function. The test has been used for the assessment of exocrine pancreatic deficiency in protein deficient patas monkeys (Gyr et al., 1975). In the present study we report the preliminary results with this new, simple pancreatic function test (PFT) in man.

\section{Methods \\ PATIENTS \\ Controls}

Thirteen healthy volunteers (10 men and three women aged 19 to 35 years) were taken as normal

${ }^{1}$ Address for reprint requests: Dr K. Gyr, Department of Gastroenterology, Kantonsspital, CH-4004 Basel, Switzerland.

Received for publication 2 October 1975. subjects, and 11 patients (five men and six women aged 16 to 58 years) without organic disease of the gastrointestinal tract served as controls. Pancreatic disease was excluded after a thorough clinical examination and by the Lundh test in eight normal subjects and in all control patients. The interval between the PFT and the Lundh tests did not exceed one month in the normal subjects and 6.5 months in the control patients. The sequence of the tests was chosen randomly for the normal subjects only.

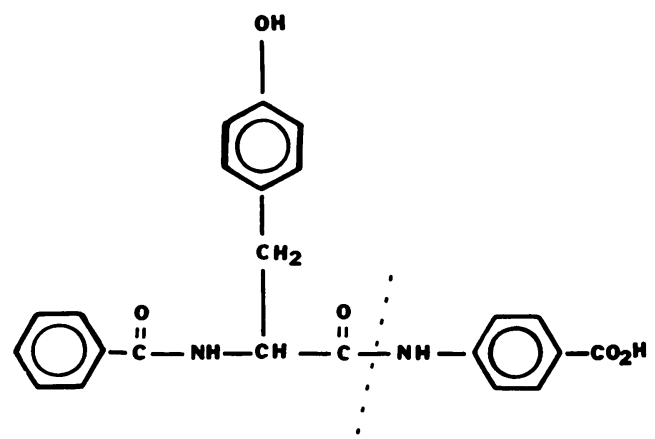

Fig. 1 Formula of N-benzoyl-L-tyrosyl-PABA. The peptide bond split by chymotrypsin is marked by an interrupted line 
Patients with pancreatic disease

Twenty-eight patients with proven pancreatic disease either acute (13) or chronic (15; Table 1), were investigated. In all but five, exocrine pancreatic function was assessed by the Lundh test. Three of the five cases without a Lundh test had chronic pancreatitis proven by surgery or at necropsy and two acute pancreatitis verified by clinical signs and the elevation of serum amylase. The median of the intervals between the PFT and the Lundh test was eight days (one day to 11 months) in acute pancreatitis and 13.5 days (two days to 22 months) in chronic pancreatic disease. The interval of 22 months was justified in a well-established case of chronic pancreatitis documented by two Lundh tests with trypsin activities below $2 \mu \mathrm{Eq} \mathrm{H}+/ \mathrm{min} / \mathrm{ml}$ one year apart.

Patients with non-pancreatic disease

Twelve patients with various gastrointestinal diseases other than pancreatic were examined (Table 2). Nine of these patients had a Lundh test as well.

All subjects tested had creatinine values below $2 \mathrm{mg} \%$, so that interference due to seriously impaired renal function was unlikely.

The purpose and procedure of the study were explained to each person tested. All subiects had to give a formal consent.

\section{Procedure}

PFT

Patients to be tested were fasted overnight. All drugs were discontinued at least 24 hours before the investigation. To produce a stimulus similar to the one in the Lundh test, the test peptide, $1 \mathrm{~g} \mathrm{~N}$ benzoyl-L-tyrosyl-PABA, was added to $150 \mathrm{ml}$ of the Lundh test meal (Lundh, 1962) and administered orally. Thereafter, food was withheld. However, the patients were encouraged to drink water or unsweetened tea to ensure sufficient diuresis. In those experiments extending over 24 hours, meals

\begin{tabular}{|c|c|c|c|c|c|}
\hline \multirow[t]{2}{*}{ Name } & \multirow{2}{*}{$\begin{array}{l}\text { Age } \\
(y r)\end{array}$} & \multirow[t]{2}{*}{$\operatorname{Sex}$} & \multirow{2}{*}{$\begin{array}{l}\text { 6-hour urinary excretion } \\
\text { of } P A B A(\%)\end{array}$} & \multicolumn{2}{|c|}{ Diagnosis of chronic pancreatic disease } \\
\hline & & & & $\begin{array}{l}\text { Lundh test TMC } \\
I U^{*} / m l\end{array}$ & Other \\
\hline $\begin{array}{l}\text { A.P. } \\
\text { G.H. } \\
\text { E.Sp. } \\
\text { B.St. } \\
\text { H.W. } \\
\text { C.M. } \\
\text { H.G. } \\
\text { F.Stoe. } \\
\text { S.B. } \\
\text { H.Sch. } \\
\text { A.F. } \\
\text { R.H. } \\
\text { F.Sto. } \\
\text { E.Z. } \\
\text { A.E. } \\
\text { Normal }\end{array}$ & $\begin{array}{l}60 \\
80 \\
53 \\
38 \\
84 \\
52 \\
51 \\
61 \\
25 \\
48 \\
33 \\
49 \\
79 \\
52 \\
70\end{array}$ & $\begin{array}{l}\mathbf{M} \\
\mathbf{M} \\
\mathbf{M} \\
\mathbf{M} \\
\mathbf{M} \\
\mathbf{M} \\
\mathbf{M} \\
\mathbf{M} \\
\mathbf{F} \\
\mathbf{M} \\
\mathbf{M} \\
\mathbf{M} \\
\mathbf{F} \\
\mathbf{M} \\
\mathbf{M}\end{array}$ & $\begin{array}{c}20.2 \\
26 \cdot 8 \\
11 \cdot 5 \\
19 \cdot 7 \\
8.4 \\
16 \cdot 7 \\
15 \cdot 4 \\
23 \cdot 0 \\
23 \cdot 8 \\
31 \cdot 9 \\
37 \cdot 0 \\
35 \cdot 8 \\
33 \cdot 4 \\
66 \cdot 3 \\
8 \cdot 5 \\
<47.0\end{array}$ & $\begin{array}{l}1.0 \\
3.0 \\
1.0 \\
0.5 \\
0 \\
1.3 \\
1.0 \\
1.0 \\
1.8 \\
4.8 \\
1.0 \\
4.5 \\
- \\
\mathbf{8 . 8}\end{array}$ & $\begin{array}{l}\text { Laparotomy: pseudocyst } \\
\text { Laparotomy } \\
\text { Laparotomy: chronic sclerosing pancreatitis } \\
X \text {-ray: pancreatic calcifications } \\
\text { Laparotomy: pseudocyst } \\
X \text {-ray: pancreatic calcifications } \\
\text { Laparotomy: pseudocyst } \\
\text { Previous pancreatectomy for insulinoma } \\
X \text {-ray: pancreatic calcifications } \\
1 \text { year after haemorrhagic pancreatitis and shock } \\
\text { Laparotomy: chronic sclerosing pancreatitis } \\
\text { Laparotomy: chronic sclerosing pancreatitis } \\
\text { Laparotomy: pseudocyst } \\
\text { Necropsy: carcinoma of head }\end{array}$ \\
\hline
\end{tabular}

Table 1 Diagnosis and results of PFT and Lundh test in patients with chronic pancreatic disease $* \mathrm{IU}=\mu \mathrm{Eq} \mathrm{H}+/ \mathrm{min} / \mathrm{ml}$.

\begin{tabular}{|c|c|c|c|c|c|}
\hline Name & $\begin{array}{l}\text { Age } \\
(y r)\end{array}$ & Sex & $\begin{array}{l}\text { 6-hour urinary excretion } \\
\text { of } P A B A \text { in } \%\end{array}$ & $\begin{array}{l}T M C \\
I U^{*} / m l\end{array}$ & Diagnosis \\
\hline $\begin{array}{l}\text { E.R. } \\
\text { I.V. } \\
\text { M.S. } \\
\text { M.M. } \\
\text { J.V. } \\
\text { J.M. } \\
\text { S.O. } \\
\text { F.G. } \\
\text { M.D. } \\
\text { L.G. } \\
\text { E.B. } \\
\text { F.B. }\end{array}$ & $\begin{array}{l}63 \\
48 \\
56 \\
58 \\
59 \\
65 \\
50 \\
74 \\
49 \\
65 \\
22 \\
43\end{array}$ & $\begin{array}{l}\mathbf{M} \\
\mathbf{F} \\
\mathbf{F} \\
\mathbf{M} \\
\mathbf{M} \\
\mathbf{M} \\
\mathbf{F} \\
\mathbf{F} \\
\mathbf{M} \\
\mathbf{F} \\
\mathbf{M} \\
\mathbf{M}\end{array}$ & $\begin{array}{l}56 \cdot 3 \\
56 \cdot 3 \\
65 \cdot 8 \\
71 \cdot 9 \\
64 \cdot 3 \\
39 \cdot 8 \\
58 \cdot 3 \\
32 \cdot 9 \\
47 \cdot 3 \\
54 \cdot 6 \\
48 \cdot 9 \\
51 \cdot 3\end{array}$ & $\begin{array}{r}27 \cdot 8 \\
11 \cdot 5 \\
10 \cdot 0 \\
9 \cdot 3 \\
7 \cdot 8 \\
15 \cdot 8 \\
\frac{18 \cdot 6}{11 \cdot 5} \\
\frac{11 \cdot 5}{11 \cdot 5}\end{array}$ & $\begin{array}{l}\text { Cholecystitis } \\
\text { Primary biliary cirrhosis } \\
\text { Chronic active hepatitis } \\
\text { Chronic active hepatitis } \\
\text { Alcoholic cirrhosis } \\
\text { Alcoholic cirrhosis } \\
\text { Gluten sens. enteropathy } \\
\text { Gluten sens. enteropathy } \\
\text { Active duodenal ulcer } \\
\text { Active gsatric uleer } \\
\text { Giardiasis, amebiasis } \\
\text { Diabetes mellitus, alcoholism }\end{array}$ \\
\hline
\end{tabular}

Table 2 Results of PFT and Lundh test in patients with various gastrointestinal diseases

$* \mathrm{IU}=\mu \mathrm{Eq} \mathrm{H}+/ \mathrm{min} / \mathrm{ml} .3$ 
were allowed after the six hour urine collection had been completed.

A one hour control collection of urine was taken before the administration of the peptide. After ingestion of the test meal, urine collections were made at the time stated in each experiment. The concentration of aromatic amines was determined by the Bratton-Marshall method as modified by Smith et al. (1945) by means of a Vitatron Digital Concentration Photometer at $546 \mathrm{~nm}$ wave length. Results were highly reproducible $(r=0.998$; $P<0.001$ ). Background urinary aromatic amines were negligible and were not corrected for unless there was an obvious contamination by drugs containing other para-amino-benzoyl derivates such as sulphonamides and sulphonyl urea compounds. The term PABA is used in this study to denote aromatic amines since the bulk of the urinary aromatic amines originated from orally administered peptide-PABA. Results were conveyed as percentage of PABA recovered in the urine as compared with the applied dose.

Since the peptide was not available on the market for use in man, it was synthesized for this investigation. The substance obtained was equivalent in purity to that described by de Benneville et al. (1972): melting point $242-243^{\circ} \mathrm{C}$, equilibrium cleavage $99.5 \%[\alpha]^{25} \mathrm{D}+87.0^{\circ}$ (de Benneville et al.: $243-244^{\circ} \mathrm{C}$ and $87.0^{\circ}$ respectively). The peptide was used in the form of its sodium salt, which, in contrast with its acid form, is highly water soluble. Administration of the peptide to rats and mice did not produce any signs of acute toxicity with respect to the amount applied to man.

The peptide was given in a dose of $1 \mathrm{~g}$, which is equivalent to $320 \mathrm{mg}$ PABA (approximately $5 \mathrm{mg}$ PABA per $\mathrm{kg}$ body weight used by Imondi $e t$ al., 1972 in dogs).

\section{LUNDH TEST}

The Lundh test, a routine procedure in our department, was performed as described by Aenishaenslin et al. (1973) and Mottaleb et al. (1973). The trypsin mean concentration (TMC) was determined in two hour collections of duodenal contents according to the method of Wiggins (1967) and expressed in $\mu \mathrm{Eq} \mathrm{H}^{+} / \mathrm{min} / \mathrm{ml}$ (IU). A TMC below $8.8 \mu \mathrm{Eq}$ $\mathrm{H}^{+} / \mathrm{min} / \mathrm{ml}$ was considered abnormal (Aenishaenslin et al., 1973; Gyr et al., 1975).

STATISTICAL ANALYSIS

Student's two sample $t$ test and tests for paired data as well as regression analysis were performed according to Remington and Schork (1970).
Results

Eighty-five PFT and 51 Lundh tests were performed on 64 subjects (Figs. 2, 3).

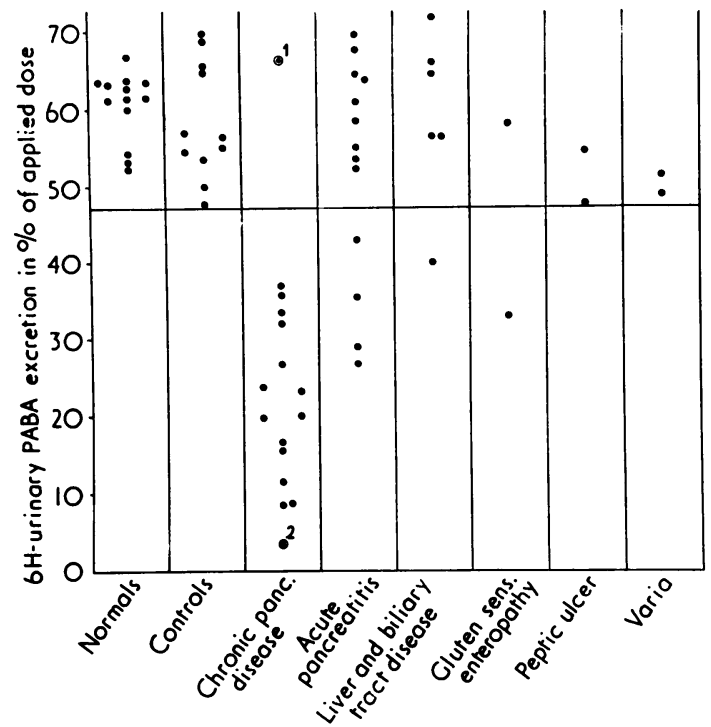

Fig. 2 Urinary PABA excretion (six hour csllection) for the 64 subjects under study according to diagnosis. The horizontal line is the lower limit of normal calculated from the controls. (Mean - 2SD). 1 Patient E.Z. (Table I) before total pancreatectomy. $\odot 2$ Patient E.Z. (Table 1) after total pancreatectomy.

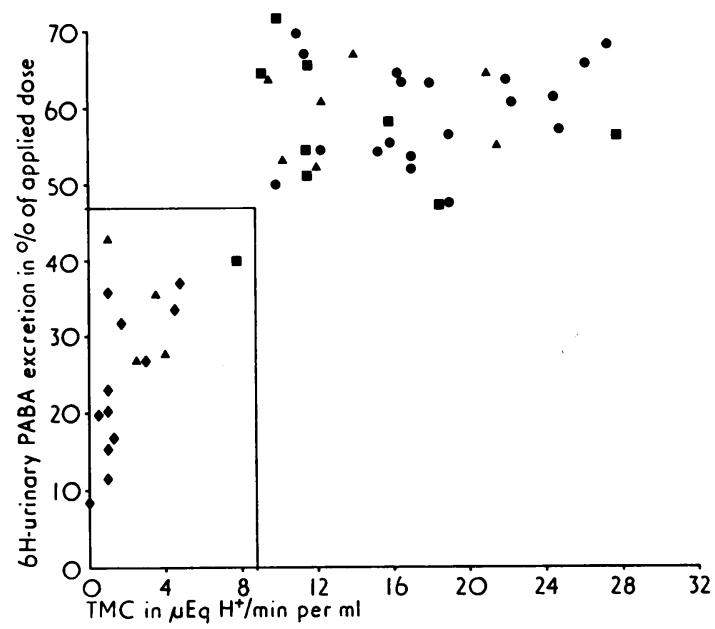

Fig. 3 Comparison of six hour urinary $P A B A$ excretion and Lundh test in 19 controls (O), 11 patients after acute pancreatitis $(\mathbf{\Delta}), 12$ patients with chronic pancreatic disease $(\boldsymbol{\downarrow})$, and nine patients with various diseases of the liver and the gastrointestinal tract $(\square)$. The horizontal and vertical lines represent the lower limits of normal for the two test procedures. 
CONTROLS

In search of the appropriate urinary collection period, the cumulative recovery of PABA in the urine was determined at two hour intervals in 10 normal subjects and 10 control patients. In both groups the coefficient of variation reached the lowest level at the six hour mark. It did not decrease further when PABA excretion was determined in eight and 24 hour collections. Therefore, it was decided to measure PABA excretion in a control and a six hour collection of urine only. The data for the 24 control subjects are given in Table 3 . The lower and upper limits of normal for the six hour urinary PABA excretion expressed as 2 standard deviations below or above the mean of $59.6 \%$ were $47.4 \%$ and $71.8 \%$ respectively of the ingested dose of peptide-PABA (Table 3 ).

\begin{tabular}{lllll}
\hline Subjects & \multicolumn{4}{l}{$\begin{array}{l}\text { 6-hour urinary excretion of PABA in \% of applied } \\
\text { dose }\end{array}$} \\
\cline { 2 - 5 } & $N$ & Mean $\pm 2 S D^{*}$ & Range & $C V(\%) \dagger$ \\
\hline Normal & 13 & $60 \cdot 6 \pm 9 \cdot 2$ & $52 \cdot 2-66 \cdot 9$ & $7 \cdot 5$ \\
Control & 11 & $58 \cdot 5 \pm 15 \cdot 2$ & $47.6-69 \cdot 7$ & $12 \cdot 9$ \\
Total & 24 & $59 \cdot 6 \pm 12 \cdot 2$ & $47.6-69 \cdot 7$ & $10 \cdot 2$ \\
& & & & \\
\hline
\end{tabular}

Table 3 Analysis of variables obtained from six-hour urinary excretion of PABA in 24 controls

*SD = Standard deviation

$+\mathrm{CV}=$ Coefficient of variation $(\mathrm{SD} /$ mean $\times 100)$

Reproducibility of the PFT was tested in 10 subjects, of whom nine were controls and one was a patient with exocrine pancreatic deficiency. A significant correlation was found among replicate tests $(y=4.9+0.895 \mathrm{x}, r=0.899, \mathrm{P}<0.001)$.

For comparison, $320 \mathrm{mg}$ pure para-aminobenzoic acid-equivalent to $1 \mathrm{~g}$ peptide-was administered orally to five normal subjects in a test meal and the extent of its urinary excretion measured at two hour intervals. Only a six hour collection of urine was performed in another normal subject. A mean of $75.7 \pm 7.5 \%$ (mean \pm SD) of the applied PABA was excreted by the six normal subjects in six hours, producing a normal range from 60.7 to $90.7 \%$. Excretion of orally administered pure PABA in the first two hours significantly $(P<0.005)$ exceeded the excretion after ingestion of the peptide.

\section{PATIENTS WITH CHRONIC PANCREATIC DISEASE}

Fifteen patients with proven chronic pancreatic disease (Fig. 2) and exocrine pancreatic deficiency excreted significantly less PABA than the control group ( $P<0.001$; Fig. 2). With the exception of one case (E.Z., Table 1 ) the results were all well below $47 \%$, the lower limit of normal calculated from the control group. Patient E.Z. underwent total pancreatectomy for persistent pain. On operation a cystic tumour of the fibrosed head of the pancreas was found. Histologically, the inflammation was localized to the head, with normal tissue in the body and tail. The PFT dropped to $3.9 \%$ after the operation.

Pure para-aminobenzoic acid was administered to one patient of this group and the amount excreted was within the normal range (patient C.M., Table 1). Thus, any possible cause for the decreased excretion of PABA arising from disturbances of absorption, metabolism, and renal excretion of PABA could be excluded.

In the group with exocrine pancreatic deficiency, a significant correlation between PFT and Lundh test results was observed $(r=0.681, \mathrm{P}<0.05)$.

\section{PATIENTS WITH ACUTE PANCREATITIS}

Patients with an attack of acute pancreatitis were not tested until symptoms had subsided and pancreatic enzymes in blood and urine had returned to normal (Fig. 2). The results showed a wide spectrum ranging from normal to abnormal values, both for PFT and Lundh test. One patient showed an abnormal result of the Lundh test just after the attack, one year before the present investigation. His exocrine pancreatic function recovered, as was shown by the PFT and the repeat Lundh test. Recovery of the PFT was also noted in two other patients during follow-up.

PATIENTS WITH NON-PANCREATIC DISEASE Of the two patients with gluten sensitive enteropathy (Table 2) one had a normal PFT and Lundh test. This patient did not suffer from diarrhoea at the time of investigation, although intestinal biopsy showed subtotal villous atrophy. The other patient had a PFT test below normal. When pure paraaminobenzoic acid was given to this patient, its excretion was found to be slightly below the lower limit of normal (53.4\%). A period of severe diarrhoea due to dietary errors had immediately preceded the PFT test.

In Table 2, patients with various gastrointestinal diseases other than sprue are presented. Only one (J.M.) had an abnormal function test. This patient had a history of heavy alcohol intake.

SIDE-EFFECTS

No side-effects or complications were noted in connection with the administration of the test peptide. In eight controls, glutamic oxaloacetic and glutamic pyruvic transaminases, alkaline phosphatase, bilirubin, sodium, potassium, urea, and 
creatinine were determined in the serum before administration of the peptide and at the end of PFT (Table 4). All results were within normal range.

\section{Discussion}

The present study reports the first experiences with the oral administration of N-benzoyl-L-tyrosylPABA as a new test of exocrine pancreatic function in man (PFT). The difference in urinary PABA excretion shown between controls and patients with exocrine pancreatic deficiency was highly significant. With one exception, no overlap of the individual results was observed. There was a significant correlation between Lundh test results and PFT in patients with pancreatic insufficiency. Although the PFT is based on chymotrypsin activity and the Lundh test evaluates trypsin secretion, the comparison of the results is justified, since a parallel secretion of the different pancreatic enzymes is reported by many authors (Burton et al., 1960; Dreiling and Janowitz, 1962; Lundh, 1962).

Subtotal villous atrophy was linked with a normal PFT and Lundh test in one patient and a decreased PFT in the other. A comparison was not possible since the Lundh test was refused by that patient. The excretion of orally administered pure PABA was slightly below the normal limit. However, in this case, intestinal absorption might have been reduced because of severe diarrhoea. Impaired renal excretion and disturbed liver metabolism were not evident by biochemical and histological examination in this patient.

Only one of the patients with non-pancreatic disease other than sprue had a low result of PFT and Lundh test. This may have been a sign of exocrine pancreatic disease due to excessive alcoholism.

The present data do not permit conclusions relating to the value of the PFT in the intermediate type of exocrine pancreatic deficiency (Aenishaenslin et al., 1973; Mottaleb et al., 1973). It can be seen from the present PFT data in patients with exocrine pancreatic deficiency (Fig. 3) that the PFT is likely to be abnormal when the TMC is at the lower limit of normal set by Mottaleb et al. (1973) - that is, $6 \mu \mathrm{Eq} \mathrm{H} / \mathrm{min} / \mathrm{ml}$.

In chronic liver disease, impaired excretion of PABA in high doses (Tabor et al., 1947) and decreased metabolism have been described (Deiss and Cohen, 1950). However, we observed a normal PFT in four patients with chronic active liver disease and alcoholic cirrhosis, as well as in a sprue patient with concomitant elevation of transaminases. It is not likely that liver disease interferes with the elimination of the small amount of PABA given (320 mg) in the PFT unless the liver function is severely impaired.

Impaired renal function up to a serum creatinine of $2 \mathrm{mg} \%$ did not interfere with the PABA excretion. Patients with higher serum creatinine levels were excluded from the study.

The test procedure was very well tolerated by all subjects. It was shown to be simpler and more comfortable than the classical intubation tests. No signs of acute toxicity were observed. A six hour urine collection appeared to be sufficient for routine purpose. Contamination of the urine by sulpha drugs may cause false results. To avoid this problem, all drugs should be discontinued at least two days before the test and a control urine sample collected immediately before the administration of the peptide. Contamination by food containing PABA was not seen.

These results indicate that the PFT is useful in the diagnosis of exocrine pancreatic insufficiency, especially in chronic pancreatitis. More studies will be required to define the exact place of PFT in the diagnosis of pancreatitis.

The authors wish to thank A. R. Imondi for reviewing the manuscript, Mrs Tonco for her technical assistance, Dr May Zimmerli for correcting and Mrs C. Frei for typing the manuscript.

\begin{tabular}{|c|c|c|c|c|}
\hline \multirow[t]{2}{*}{ Parameter } & \multirow[t]{2}{*}{ Normal range } & \multicolumn{2}{|c|}{ Peptide administration } & \multirow[t]{2}{*}{$P+$} \\
\hline & & Before & After & \\
\hline Potassium (mval/1) & $3 \cdot 3-5 \cdot 1$ & $4.6 \pm 0.34$ & $4.0 \pm 0.13$ & $<0.05$ \\
\hline Urea $(\mathrm{mg} / \mathrm{dl})$ & $20-40$ & $27.8 \pm 3.59$ & $25 \cdot 5 \pm 3.69$ & NS \\
\hline Creatinine, (mg/dl) & $0.6-1.4$ & $0.93 \pm 0.08$ & $0.83 \pm 0.06$ & NS \\
\hline Bilirubin, (mg/dl) & $<0.9$ & $0.64 \pm 0.05$ & $0.76 \pm 0.07$ & $<0.02$ \\
\hline Oxaloacetic trans. (IU/l) & $6-23$ & $12 \cdot 7 \pm 2 \cdot 29$ & $12.4 \pm 1.74$ & NS \\
\hline Glutamic pyruv. trans. (IU/l) & $5-27$ & $11.5 \pm 3.05$ & $12.9 \pm 2.73$ & $<0.05$ \\
\hline
\end{tabular}

Table 4 Serum parameters in eight controls before and six hours after administration of peptide

$t_{\text {Level of significance. }}^{\text {Mean } \pm \text { SEM. }}$ 


\section{References}

Aenishaenslin, W. H., Kayasseh, L., and Stalder, G. A. (1973). Die Pankreasfunktionspruefung mit dem LundhTest. Deutsche Medizinische Wochenschrift, 98, 2192-2196.

Burton, P., Evans, D. G., Harper, A. A., Howat, H. T., Oleesky, S., Scott, J., and Varley, H. (1960). A test of pancreatic function in man based on the analysis of duodenal contents after administration of secretin and pancreozymin. Gut, 1, 111-124.

De Benneville, R. L., Godfrey, J. W., Sims, H. J., and Imondi, A. R. (1972). New substrates for a pancraetic exocrine function test. Journal of Medical Chemistry, 15, 1098-1100.

Deiss, W. P., and Cohen, Ph. P. (1950). Studies in paraaminohippuric acid synthesis in the human: its application as a liver function test. Journal of Clinical Investigation, 29, 1014-1020.

Dreiling, D. A., and Janowitz, H. D. (1962). The Measurement of Pancreatic Secretory Function, p. 225-252. Ciba Foundation Symposium. Churchill: London.

Gyr, K., Agrawal, N. M., Felsenfeld, O., and Font, R. G. (1975). Comparative study of secretin and Lundh test. American Journal of Digestive Diseases, 20, 506-512.

Gyr, K., Wolf, R. H., Imondi, A. R., and Felsenfeld, $\mathbf{O}$. (1975). Exocrine pancreatic function in protein deficient patas monkeys studied by means of a test meal and an indirect pancreatic function test (PFT). Gastroenterology, 68, 488-494.

Imondi, A. R., Stradley, R. P., and Wohlgemuth, R. L. (1972). Synthetic peptides in the diagnosis of exocrine pancreatic insufficiency in animals. Gut, 13, 726-731.

Lundh, G. (1962). Pancreatic exocrine function in neoplastic and inflammatory disease: a simple and reliable new test. Gastroenterology, 42, 275-280.

Mottaleb, A., Kapp, F., Noguera, E. C. A., Kellock, T. D., Wiggins, H. S., and Waller, S. L. (1973). The Lundh test in the diagnosis of pancreatic disease: a review of five years' experience. Gut, 14, 835-841.

Remington, R. D., and Schork, M. A. (1970). Statistics with Applications to the Biological and Health Sciences. Prentice Hall: Englewood Cliffs, N.J.

Smith, H. W., Finkelstein, N., Aliminosa, L., Crawford, B., and Graber, M. (1945). The renal clearances of substituted hippuric acid derivates and other aromatic acids in dog and man. Journal of Clinical Investigation, 24, 388-404.

Tabor, C. W., Baily, J., and Smith, P. K. (1947). The metabolism of para-aminobenzoic acid in patients with diminished liver function. Federation Proceedings, 6, 376.

Wiggins, H. S. (1967). Simple method for estimating trypsin. Gut, 8, 415-416. 